\title{
THE CHANGES OF THE HUMAN DEVELOPMENT ON MICRO- REGIONAL AND SETTLEMENT LEVELS
}

\author{
A HUMÁN FEJLETTSÉG VÁLTOZÁSA KISTÉRSÉGI ÉS \\ TELEPÜLÉSI SZINTEN
}

\begin{abstract}
Katalin LIPTÁK $\mathbf{a}^{\mathrm{a}}$
${ }^{a}$ University of Miskolc, Faculty of Economics, Institute of World- and Regional Economics, Address: 3515 Miskolc-Egyetemváros, phone: +36-46-565-111/2023, e-mail: liptak.katalin@uni-miskolc.hu

Cite this article: Lipták, K. (2015). The Changes of the Human Development on Micro-Regional and Settlement Levels. Deturope, 7, 2: 275-290
\end{abstract}

\begin{abstract}
The purpose of this paper is to define and estimate the human potential of the settlements in SouthCserehát, Hungary. The human development index in the classical view can be estimated atmicroregional level with only hard distortions, to which the list of starting indicators differ from the usual indicators, such as GDP and GNI, the life expectancy at birth and the portion of taking part in education. However, the estimating calculations made for defining the human potential in a settlement level should be handled with hard restrictions, at the same time it perfectly shows the formation of the human factor in the region. As a research question the following was defined: In what range has the human potential changed on the basis of the census data and what kind of configuration changes have happened in the South-Cserehát? The aim of the study to attempt to estimate the HDI on settlement level.
\end{abstract}

Keywords: human development index, regional disparities

\section{Kivonat}

A tanulmány célja a Dél-csereháti települések humán potenciáljának a meghatározása és becslése. A klasszikus értelemben vett HDI (humán fejlettségi index) már kistérségi szinten is csak erős torzításokkal becsülhető, amelyhez a kiinduló indikátorok listája is eltér a jól megszokott indikátoroktól (úgy, mint a GDP vagy GNI, a születéskor várható átlagos élettartam és az oktatásban részt vevők aránya). A település szintü humán potenciál meghatározására készített becslőszámítások erős fenntartásokkal kezelendők, ugyanakkor a térség emberi tényezőjének az alakulását jól mutatják. Kutatási kérdésként az alábbi került meghatározásra: A Dél-Csereháton milyen mértékben változott a humán potenciál az egyes népszámlálási adatok tükrében és milyen térszerkezeti változások történtek? A tanulmány célja kísérletet tenni a települési szintü HDI becslésére.

Kulcsszavak:human fejlettségi index, regionális diszparitások

\section{INTRODUCTION}

"The precise definition of the human resources, a concept heard so often that it now almost seems a common place, is not an easy task. What is the point? It is that the human resources, the institutions contributing to their development, and the total of the social conditions and 
endowments together constitute those assets that a spatial unit disposes of." (RechnitzerSmahó 2006:8). Human development is measured in a lot of ways by many people, depending on the territorial unit and the statistical data. The highly debated HDI is used international level (NUTS 0. territorial level), regional level (NUTS 2. territorial level) created by international methodology with a good responsibility.

The HDI index consists of three major parts (Fig. 1). They can explain the complexity and purpose of the index.

- the average lifetime which can be estimated for at the time of the birth is the index of long and healthy life

- the knowledge obtained in education shows the knowledge level of a person

- the GNI per person shows the income and standard of living.

Figure 1 The parts of Human Development Index

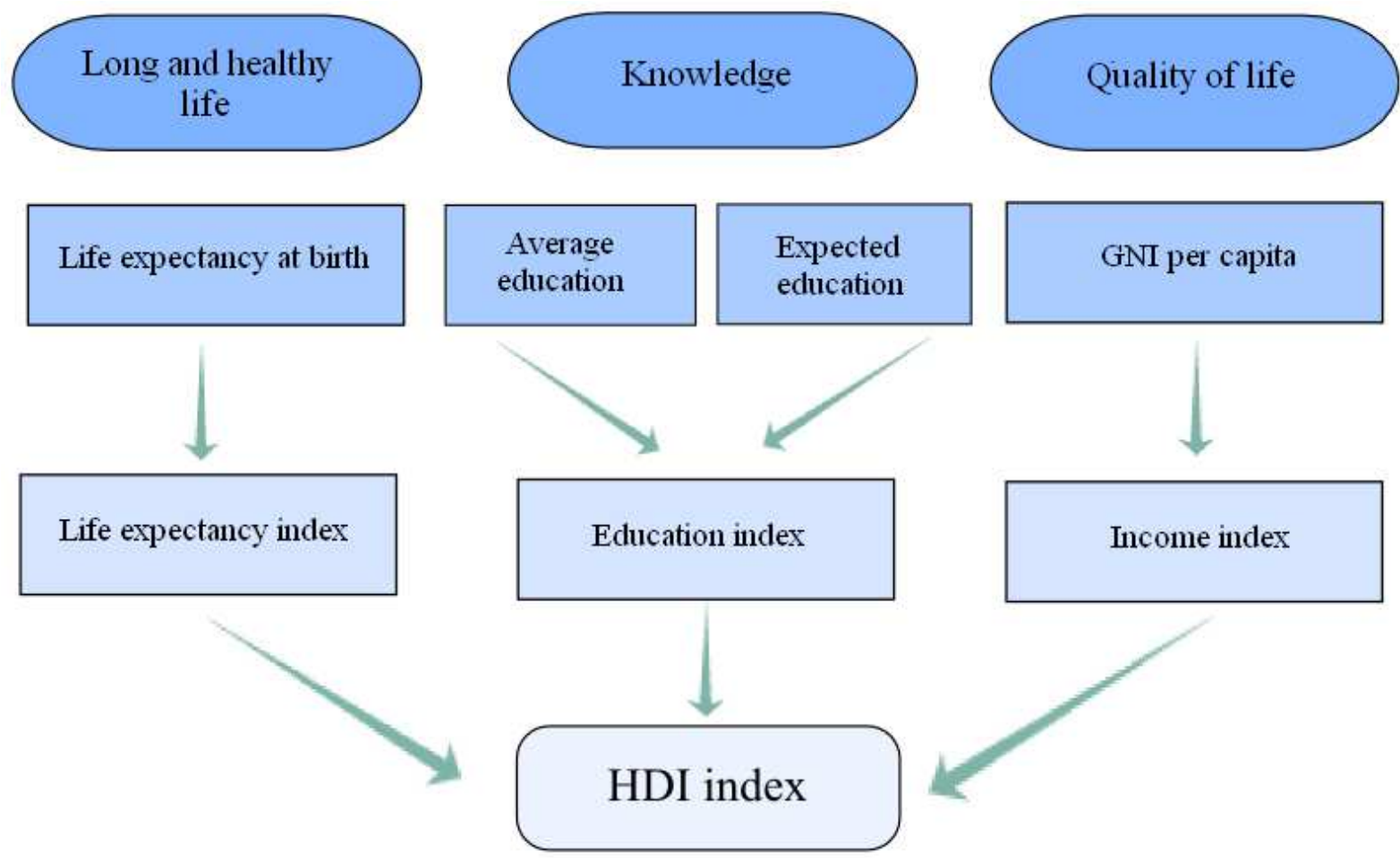

Source: Own compilation

"The Human Development Index (HDI), first introduced in the 1990 Human Development Report (UNDP: 1990), was in response to the need for a measure that could better represent human achievements in several basic capabilities (what people can do and be) than income based indices of growth and development and could provide a credible alternative to them." (Kovacevic 2010:1)

To calculate the HDI in a classical view, an average formula is used, that can be applicable for all of the parts of HDI as a self-reliant index (mutual methodology international level 
created by UNDP). To compare the relationship between indicators, terms and territorial units, we have to perform a normalization with the help of the indicators' fixed minimum and maximum values. (Kristóf 2003:1091)

The formula is the following:

$$
I_{i}=\frac{X_{i}-X_{\min }}{X_{\max }-X_{\min }}
$$

where $X_{i}$ is the actual value of variable,

$\mathrm{X}_{\max }$ is the fixed maximum value of the variable,

$\mathrm{X}_{\min }$ is the fixed minimum value of the variable.

During the calculation the minimum and maximum values were fixed by the international values in the following way (HDR 2014):

- the average lifetime which can be estimated for at the time of the birth: 20 and 85 years

- education index: expected years of schooling: $0 \%$ and $18 \%$; mean years of schooling: $0 \%$ and $15 \%$

- the GNI per person (puchasing power-parity) 100 US $\$$ and 75.000 US $\$$.

The HDI index is calculated in the following way:

1. Firstly, we calculate the index of the average lifetime.

2. Then we calculate the average education, after determining the expected education. The education index is calculated with the values of the first step indicators in the following way:

$$
I_{2}=\frac{\sqrt{a \times b}-X_{\min }}{X_{\max }-X_{\min }}
$$

3. In the next step, we calculate the modified GNI index. In the case of GNI, the natural base logarithmic transformation holds the differences in the magnitudes that are used (calculation of logarithmic serves to show the index of the decreasing increment of the income growth, and it cuts down the differences on the basis of absolute values of GNI per person), which has the following formula (Bhatnager 2002):

$$
I_{3}=\frac{\ln \left(X_{i}\right)-\ln \left(X_{\min }\right)}{\ln \left(X_{\max }\right)-\ln \left(X_{\min }\right)}
$$

4. As the final step, we determine the HDI:

$$
H D I=\sqrt[3]{I_{1} \times I_{2} \times I_{3}}
$$

The methodological of HDI calculation has changed considerably during the last two decades. The last methodological change was more significant when the former applied GDP was substituted to GNI. 


\section{THE METHODOLOGY OF THE MODIFIED HUMAN DEVELOPMENT INDEX AND THE SETTLEMENT LEVEL HUMAN POTENTIAL}

For the HDI related territorial units that are smaller than the country level during calculation of the human potential, the indicators are modified and we apply the relevant indicators to the territorial units. In territorial units smaller than the regions, we can calculate (counties: NUTS 3. level, micro regions: LAU 2. level) only the modified human development index (MHDI). (Husz 2001, Kristóf 2003, Obádovics-Kulcsár 2003, Csite-Németh 2007, Farkas 2012). In my former research I have also performed regional (Lipták 2013), and micro regional (Lipták 2009) HDI calculations as well.

Table 1 Indicator set for calculation of HDI in the case of different territorial level

\begin{tabular}{|l|l|l|}
\hline $\begin{array}{l}\text { Territorial } \\
\text { level }\end{array}$ & \multicolumn{1}{|c|}{ Name of the index } & \multicolumn{1}{|c|}{ Indicators } \\
\hline country & $\begin{array}{l}\text { Human development index } \\
\text { (HDI) }\end{array}$ & $\begin{array}{l}\text { life expectancy at birth (year) } \\
\text { average education (year) } \\
\text { expected education (year) } \\
\text { GNI per person (US\$ / person) }\end{array}$ \\
\hline region & $\begin{array}{l}\text { modified human development } \\
\text { index (MHDI) }\end{array}$ & $\begin{array}{l}\text { life expectancy at birth (year) } \\
\text { student participation all level of the education } \\
\text { compared to the full population (per cent) } \\
\text { household available net incomes (EUR/ person) }\end{array}$ \\
\hline county & $\begin{array}{l}\text { modified human development } \\
\text { index (MHDI) }\end{array}$ & $\begin{array}{l}\text { life expectancy at birth (year) } \\
\text { rate of the liberate older than 6 years within the } \\
\text { population (per cent) } \\
\text { number of the class done more than 6 years in } \\
\text { population (number of the class) } \\
\text { domestic income per person (HUF/ person) }\end{array}$ \\
\hline $\begin{array}{l}\text { micro } \\
\text { region }\end{array}$ & $\begin{array}{l}\text { micro regional human } \\
\text { development index (HDI) }\end{array}$ & $\begin{array}{l}\text { the rate of the liberate older than 6 years within the } \\
\text { population (per cent) } \\
\text { the number of the class done more than 6 years in } \\
\text { population (number of the class) } \\
\text { domestic income per person (HUF/person) } \\
\text { life expectancy at birth (year) }\end{array}$ \\
\hline settlement & $\begin{array}{l}\text { settlement human potential } \\
\text { (THP) }\end{array}$ & $\begin{array}{l}\text { average school class number in the population more } \\
\text { than 7 years old (number of the class) } \\
\text { the number of 0-14 years to 100 person over 60 } \\
\text { years (person) } \\
\text { domestic income per person (HUF/person) } \\
\text { number of dependents for 100 employed people } \\
\text { (person) }\end{array}$ \\
\hline
\end{tabular}

Source: Own compilation

For the calculations in settlement level, I used the population data from the last three censuses (Population Census 2011). I have created the development of the human factor in settlement level with the help of the following indicators: 
- Average school class number over 7 years within population (school class number), that gives information about the education standard of the given settlement living people - education index.

- The number of 0-14 years (person) and over 60 years on the base of 100 people, that shows the settlement aging similar to the aging ratio. Due to the lack of information, I applied this instead of the average lifetime which can be estimated for at the time of the birth - aging index.

- The whole domestic income per person (HUF/person) that shows the income level of the settlement - income index (the income was not deflated).

- The number of dependents for 100 people (person) (for the calculation I used the reciprocal data because the highest value reflects unfavourable processes and it can be misleading) that gives information about the level of incapacity for work - dependent index.

I didn't change the formula when creating sub-index, so it is the same as used at the country level (see Formula 1).

The applied minimum and maximum values data are highly debated, but I decided to base my thesis on all-time minimum and maximum values of the whole database. After having calculated the sub-indexes, the values of the final settlement human potential according to the UNDP, similar to the geometric mean, the product of sub-indexes is put to the fourth root.

$$
T H P=\sqrt[4]{I_{1} \times I_{2} \times I_{3} \times I_{4}}
$$

After the calculations I found the human development values of Hungarian settlements (Fig. 2). In order to obtain a better comparison, I have set up the equal interval class values of the years 1990, 2001 and 2011. The human potential values show a substantial decrease from 1990 to 2001 that is distorted with the fixed class interval values. The change is more visible from 2001 to 2011. The specific development axes in the configuration (Budapest- GyörSopron line and the region of Balaton) intensified by 2011. From the configuration models, which Gorzelak (1996) called "Middle-Europe-Boomerang formation from Gdansk to Budapest, Poznan, Wroclaw, Prague, Brno and consist the Wien-Pozsony-Budapest triangle" (Kincses-Nagy-Tóth 2012) we can see the Hungarian covered territory of Middle- EuropeBoomerang high potential values. This developing axis and its strong potential can be referenced not only for the economic performance but for the human development, as well. 
Surprising, that in Northern Hungary and Northern Great Plain regions we can see low potential values also. Explaining, that the number of dependents is growing continuously. The number of youngsters calculated to 100 people over 60 years is continuously decreasing and the education data showed improvement in the past 20 years. The income data improved as well. In 1990 Tiszaújváros had the highest human potential value (Tiszaújváros micro region), followed by Taszár (Kaposvár micro region) and Záhony (Záhony micro region). In 2001 the highest values were visible in Csapi (Nagykanizsa micro region), Vasszilvágy (Szombathely micro region), Gilvánfa (Sellye micro region). In 2011 Csapi (Nagykanizsa micro region), Telki (Budaörs micro region) and Rinyabesenyő (Nagyatád micro region) had the highest values. During the last 20 years its human potential values have decreased nearly by half, according to my calculations.

Figure 2 The human potential values of the Hungarian settlements $(1990,2001,2011)$
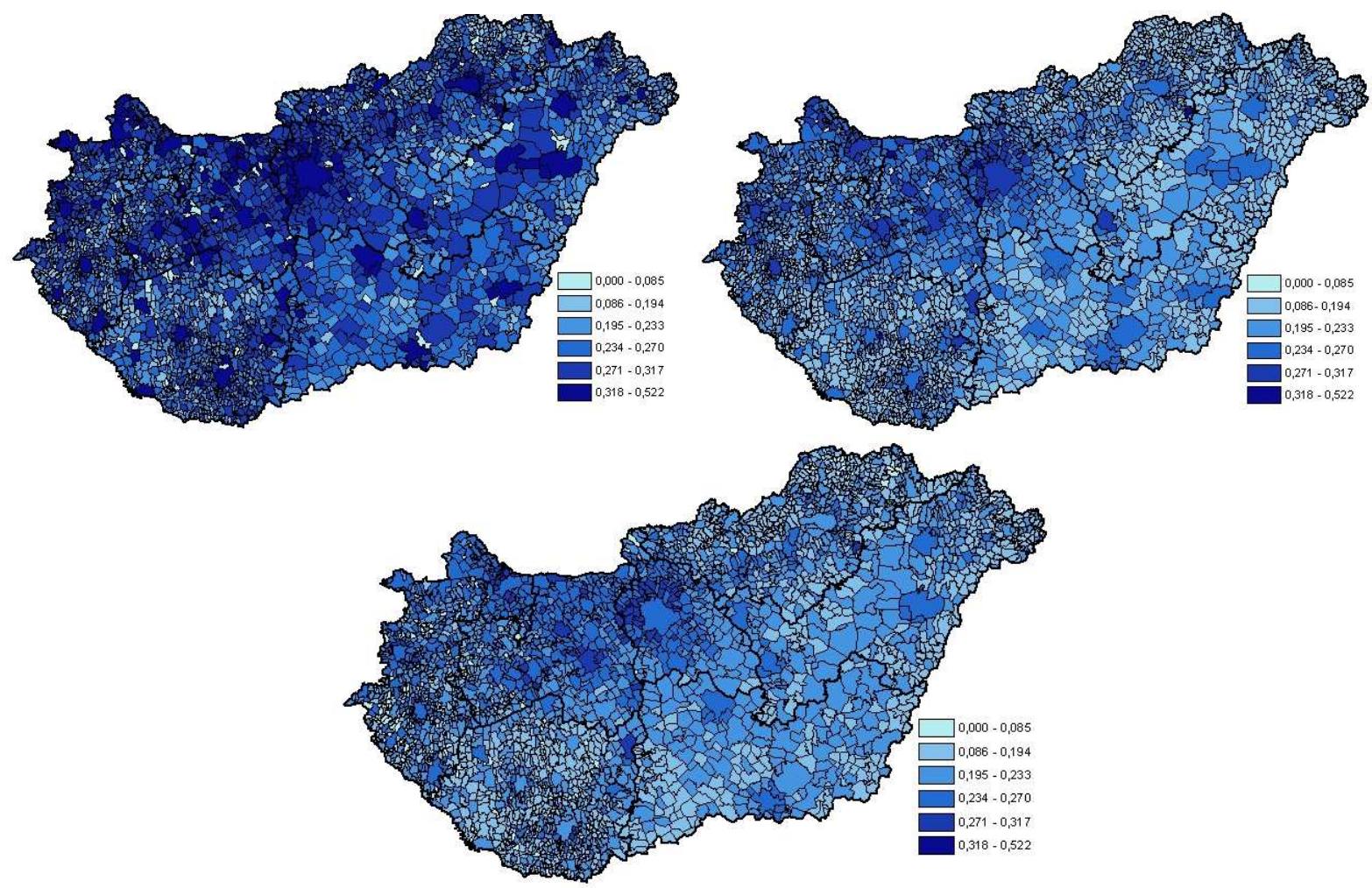

Source: Own compilation based on own calculation

With the help of the ArcGIS map editing software, I have compared the human potential values taking a basis of an average years' human potential value of a given year. Figure 3 illustrates the trend and range of the derogation from the national average. In 1990 there was a significant difference between the human development values of settlements compared to the national average. Specifically there were high numbers in those settlements where the 
derogation from the average shows a double or double and a half lower potential. By 2011 the settlement configuration was more balanced compared to the national average on the basis of human development. In 2011 the numbers were lower in those settlements where significant derogations were observable in a negative way. At the same time, the number of those settlements decreased where the human development values were double of the national average. The HDI was more balanced by 2011 or rather the regional disparities were moderated in the case of human potential.

Figure 3 The trend and range of the derogation from the average $(1990,2001,2011)$
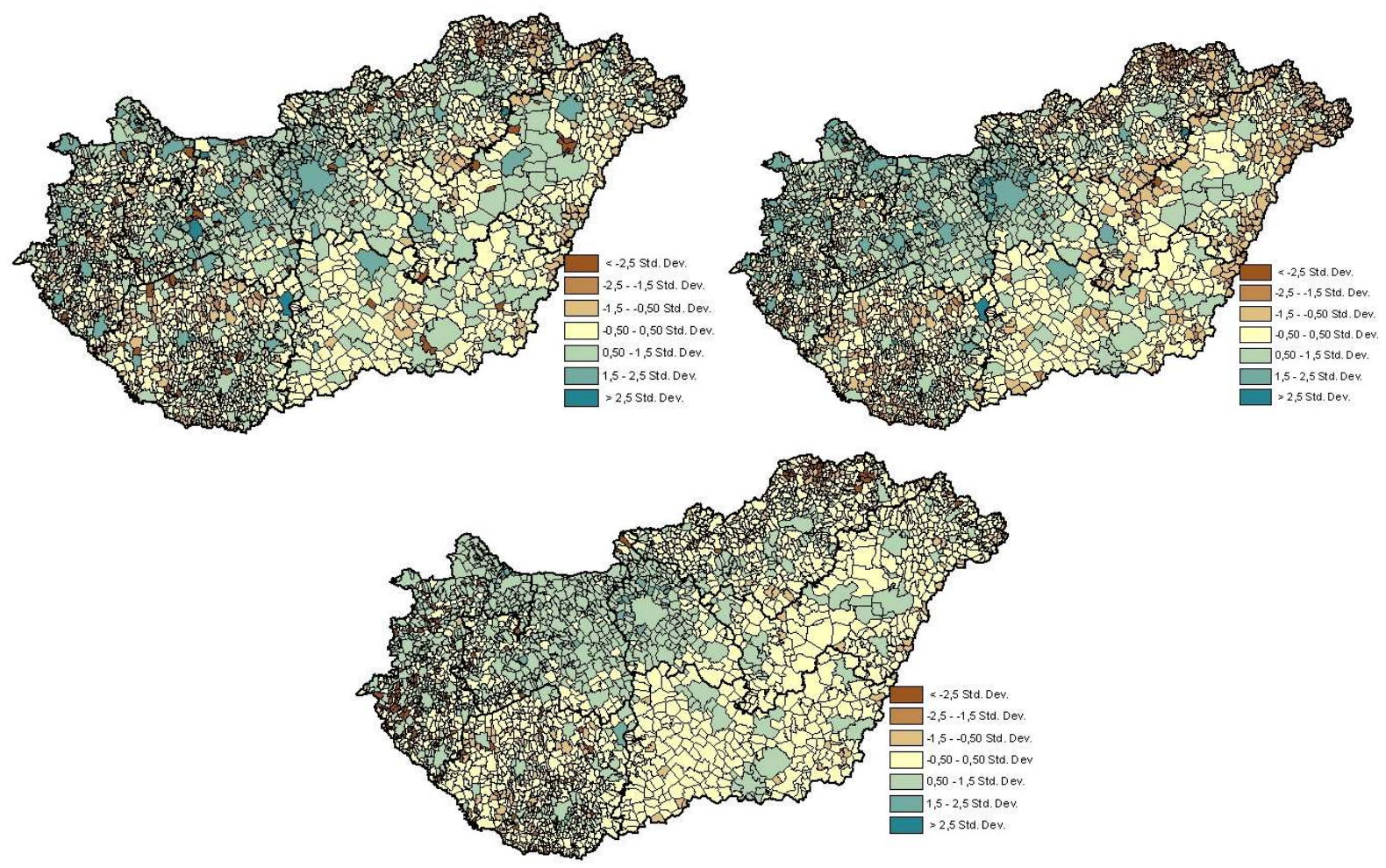

Source: Own compilation based on own calculation

\section{SOME ADDITIONAL INFORMATION ABOUT THE CSEREHÁT}

"The area bordered by the Cserehát, the Hernád and the Bódva rivers, by the southern borders of the Encs and Szikszó micro-regions and by the Slovak national border that includes the Encs micro-region (excluding the 11 villages of Zemplén county around Gönc), as well as most of the Edelény and Szikszó micro-regions, some 100 settlements. The population is nearly 91 000.” (Fig. 4) (The Cserehát Programme)

G. Fekete (2015) identified 7 main problem areas in Cserehát:

1. Inadequate macro-policy, degradable institutions

2. The demographic imbalance 
3. The own resources for livelihood are inability, dependence

4. Limited to meet needs of deprivation, poverty

5. Transport and informational isolation

6. Risk of environmental resources, undermining the ecological balance

7. The lack or weakness of network connections

Figure 4 Cserehát region and their micro-regions

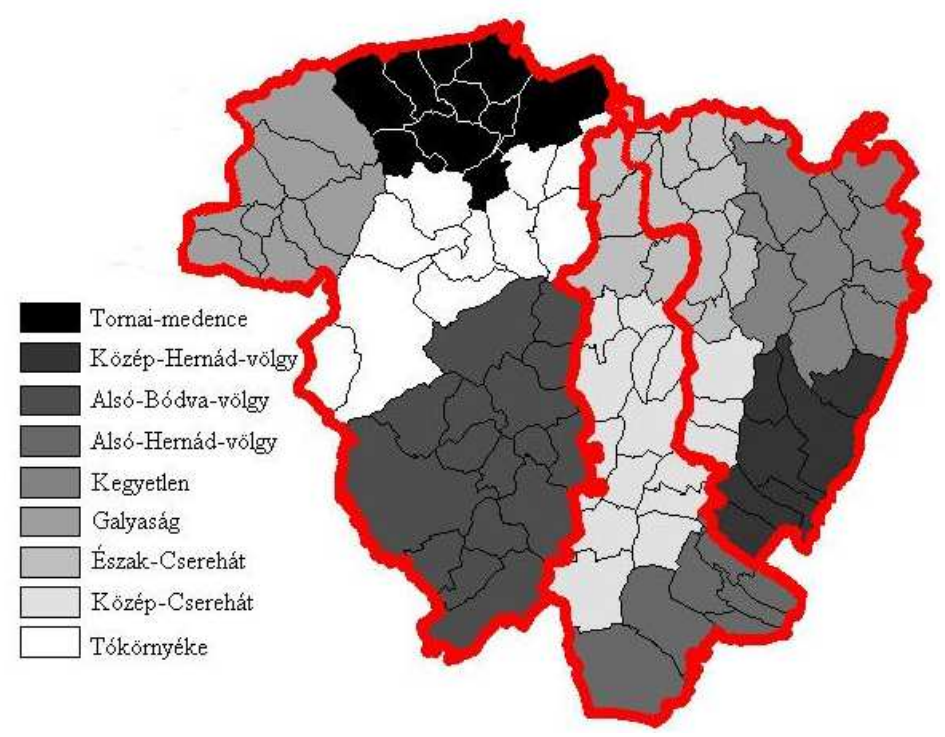

Source: G.Fekete (2015:5)

Cserehát has bad conditions on social side. Small villages with aging and fast-declining populations that are struggling with social exclusion are typical in the region. A significant part of the population struggling with social exclusion is Roma. One of the major features of the area is the bad condition of public roads. The deteriorated road quality and the seemingly irrational road network provide unfavorable conditions for possible investors. (The Cserehát Programme)

On the basis of above illustrated methodology, I have calculated the THP values for the settlements of South-Cserehát region. In the interest of comparing better results, I have analyzed the values and differences between settlements as a sub-index. In the maps, I represented the quintile, not the values, between the given years in order achieve to a better comparison (Fig. 5). The values of the education index grew dynamically in the three base years (the average in 1990 0,424, in 2001 4,453 and in 2011 0,520.) In 1990 and in 2001 were the highest value in Encs, in 2011 was in Fancsal. I divided the settlements into 5 equal parts on the basis of education index. According to the census years, the moving of the settlements between classes can be illustrated, as well. From 1990 to 2001 a significant derogation isn't 
observable, but by 2011 more settlements dropped to a lower value class from a higher quintile group, such as Felsővadász, Forró, Homrogd, Kázsmárk, Léh. At the same time improvement was observable in some settlements like: Abod, Abaújlak, Gibárt.

Figure 5 The education quintile of the settlements in South - Cserehát (1990., 2001., 2011 year)
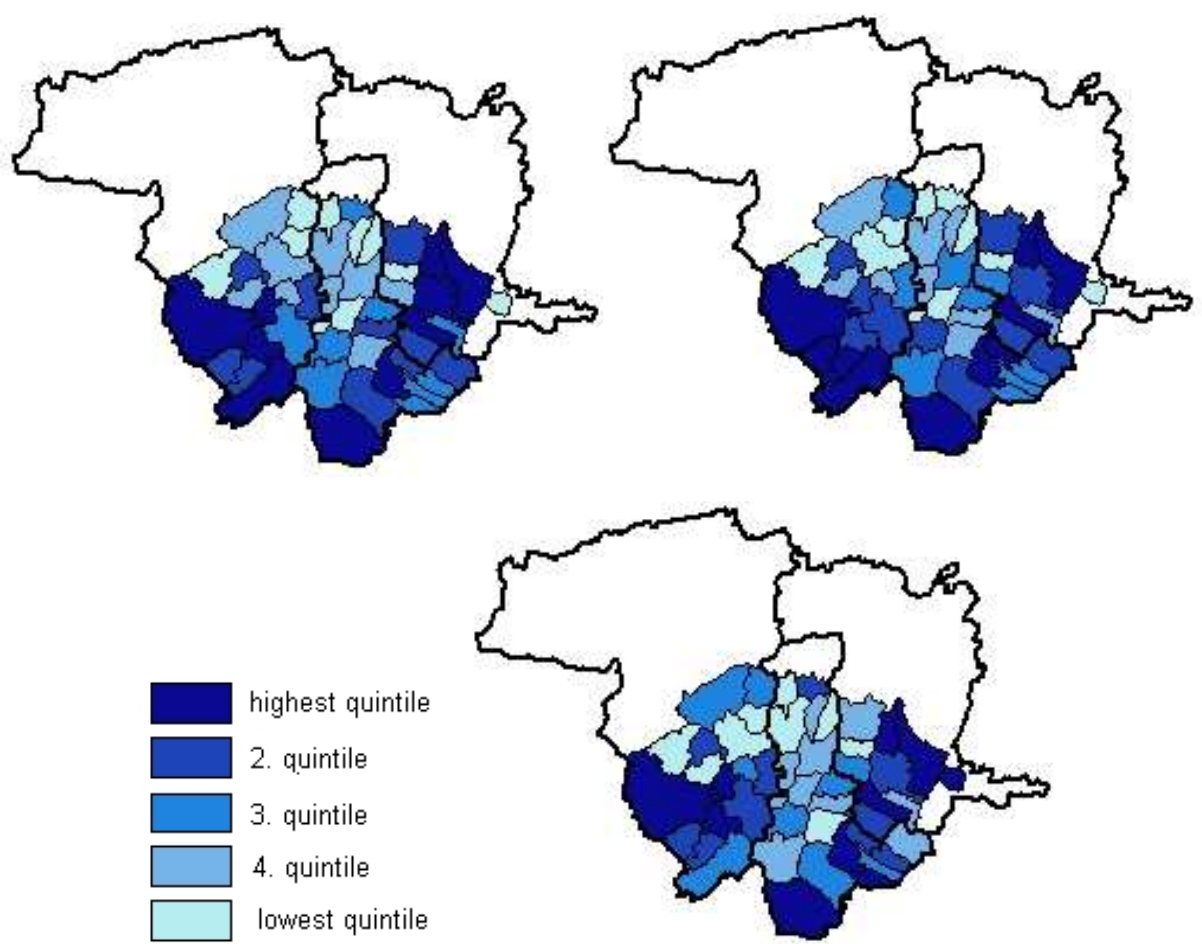

Source: Own compilation based on own calculation

Movement of settlements between the different quintiles was more significant in the case of the ageing index (Fig. 6). All in all, this sub-index shows the most significant decrease. In the case of Szikszó, the index value declined continuously or rather the number of elderly people were getting higher and higher and the number of $0-14$ years were getting lower. 
Figure 6 The aging index quintile of settlements in South- Cserehát (1990, 2001, 2011 year)
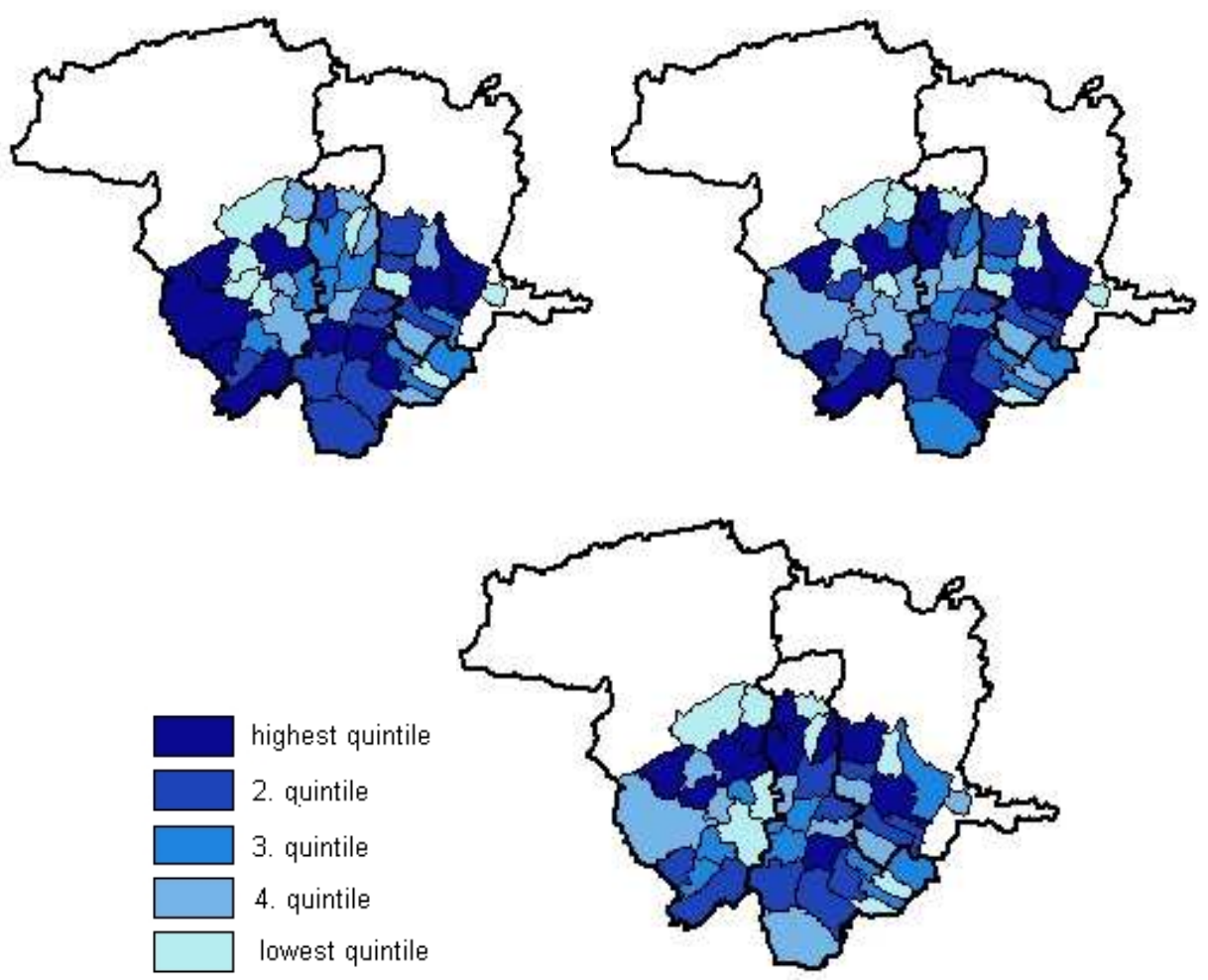

Source: Own compilation based on own calculation

The aging index values declined in Edelény, Damak, Hangács, Homrogd, Szikszó by 2001, compared to the year of 1990. The values in Nyésta, Hegymeg, Tomor, Encs, Aszaló declined from 2001 to 2011. In the case of Szakácsi, Abaújszolnok and Gibárt, the aging data of the population improved by 2011. The changes in the data of the settlements prevent us from observing the regularity and create clusters. The highest aging index was in Abaújszolnok, in 2011 with its 0,300 value. 
Figure 7 The income index quintile of the settlement in South-Cserehát (1990, 2001, 2011 year)
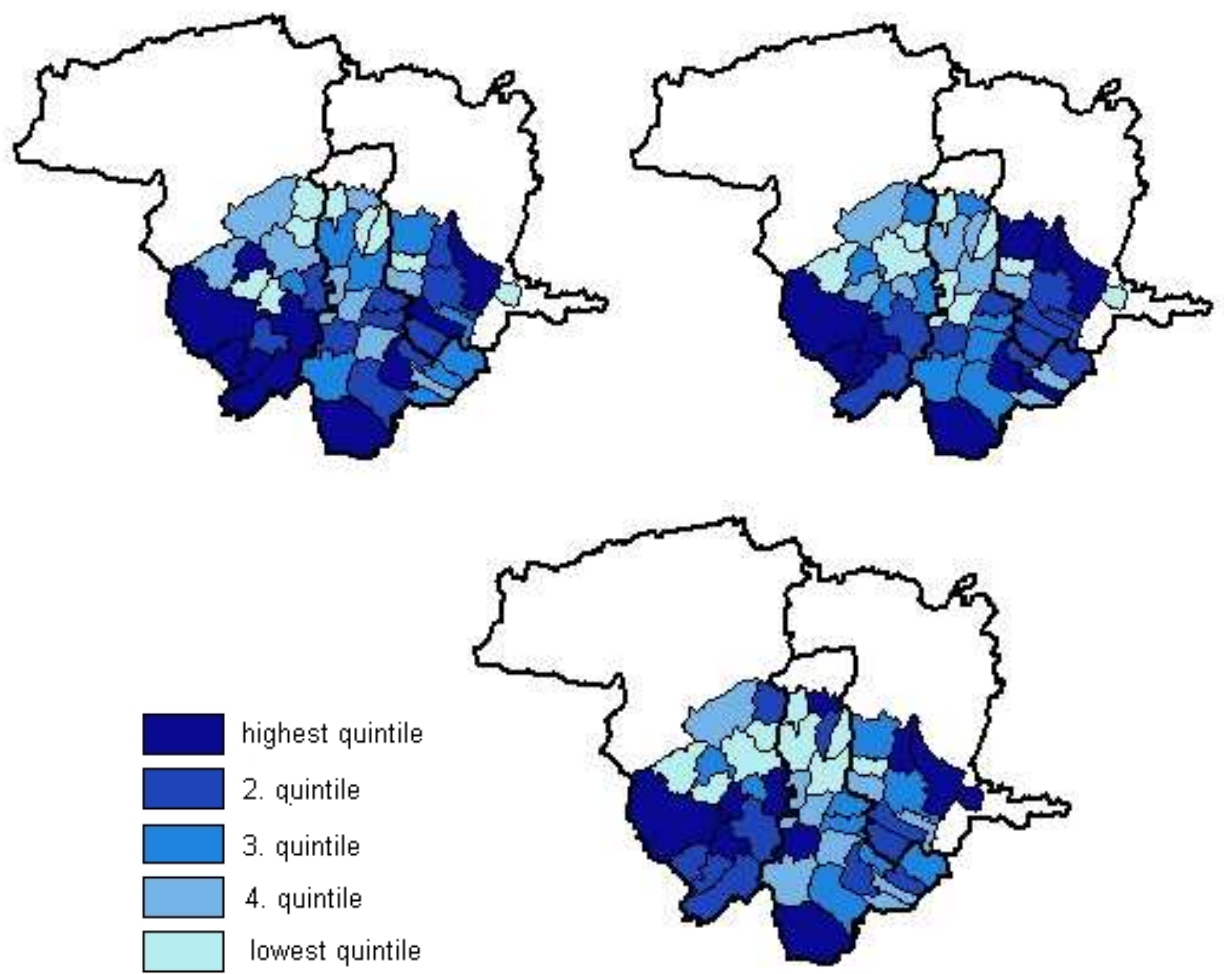

Source: Own compilation based on own calculation

Only a small range of derogation can be observed in the values of the sub-index related to the income relation (Fig. 7). By 2011 Alsóvadász, Felsővadász, Forró, Hernádszentandrás, Csobád settlements fell to a much lower quintile, so the income relations became unfavourable. In the case of Gibárt and Abaújlak, the income relations improved by 2011. The income index data of the settlements in South-Cserehát were an average of 0,162 in 1990, in 2001 it was 0,227 and increased to 0,234 by 2011 , so the average of the income values within the region were strengthened. The most developed settlement was Abaújlak in 2011 where the index value was merely 0,569 . Through the dependent index quintile we can observe the highest derogation (Fig. 8). 
Figure 8 The dependent index quintile of settlements in South-Cserehát (1990, 2001, 2011. year)

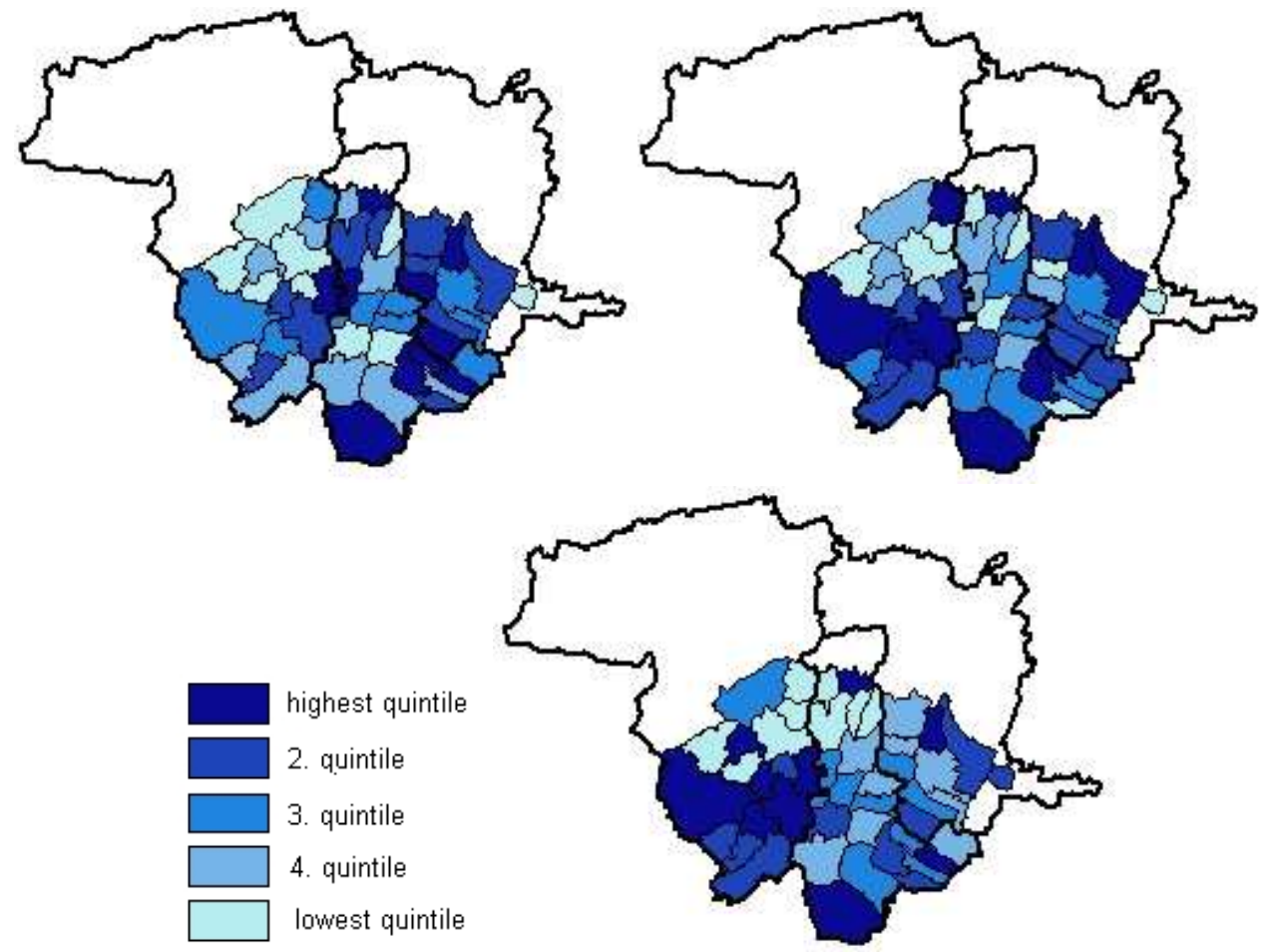

Source: Own compilation based on own calculation

The moving of the settlements between the groups was significant in both of the two periods. The average value in 1990 was 0,161 , in 2001 was 0,065 and in 2011 was 0,114 . The increment happened in 2011 due to unfavourable region processes. From the configuration point of view, change is occurred at this index. In 1990, we can draw a circle around Abod, Szendrölád, Lak, Ládbesenyő, Balajt, because the rate of the dependents were the highest in these settlements. They have created a closed settlement - circle in the South- Cserehát - but this configuration structure came apart totally by 2001 and the income relations were improved slightly. The index of this indicator started by looking at how many people out of 100 were unable to work. This change can be explained by the working opportunities that were opened in these settlements. There were not necessarily big investments or a lot of new workplaces. Rather improvement can be explained with the parent of public employment with the increasing number of people working in the public interest. By 2011 another type of configuration had shaped. Edelény reached the highest value group, so here the relation is significantly higher compared to the other settlements of the region in the field of working opportunities and income relations. In 2011 was the most unfavourable situation in the north peripheral territories of South-Cserehát (Irota, Lak, Szakácsi, Gadna, Felsővadász, Nyésta, Abaújszolnok, Szendrölád és Balajt). By 2011 the spatial structure became double poles, so 
created a settlement circle with high dependent rates and another settlement circle with significantly low dependent rates.

I have also controlled the human development of the settlements in South-Cserehát and I have showed the data moving in a separate map (Fig. 9). I took as a basis the class interval data in 1990 and every following year to be able to ensure the comparability.

Figure 9 The human potential values of South-Cserehát (1990, 2001, 2011 year)

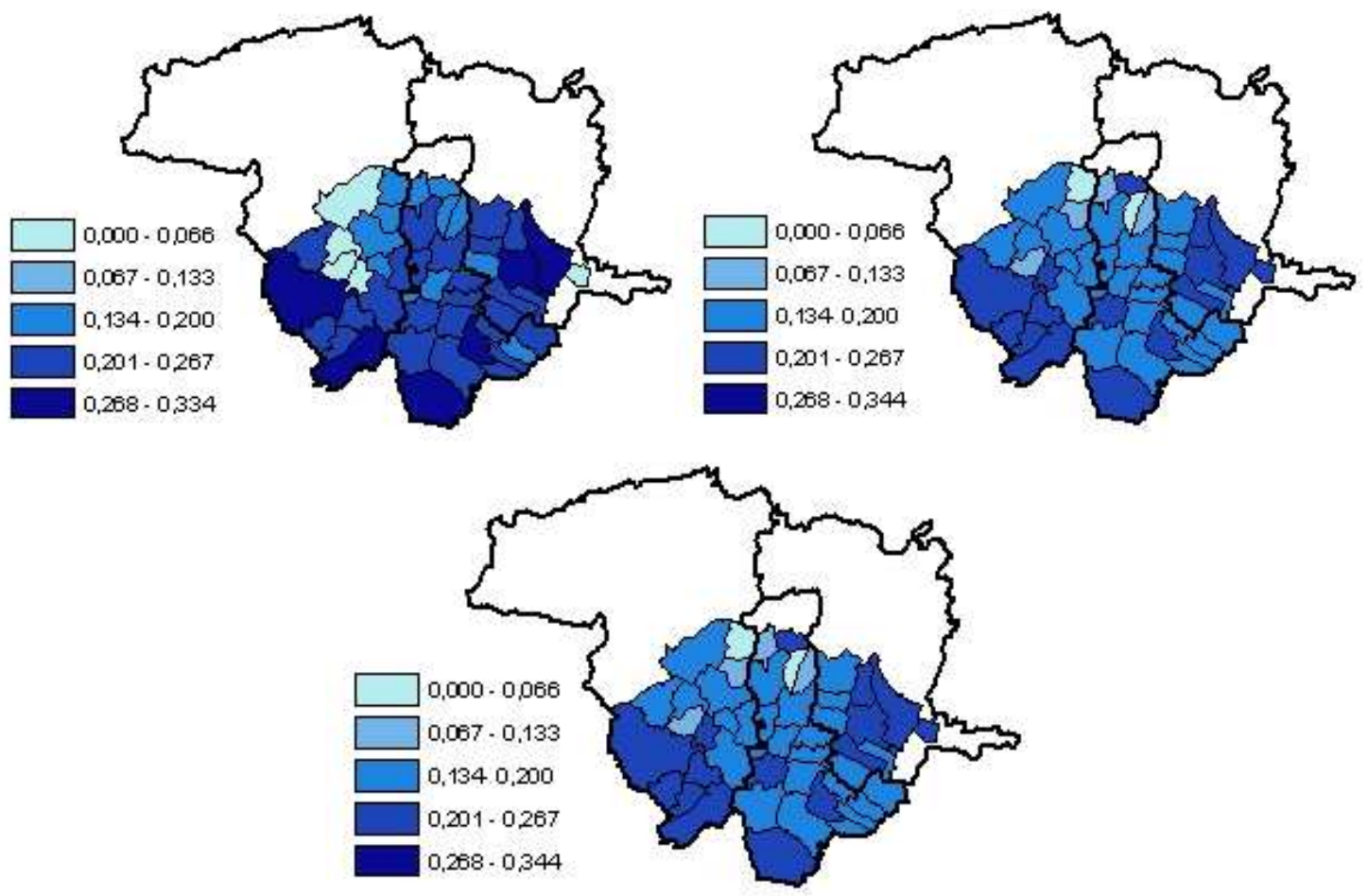

Source: Own compilation based on own calculation

In the settlements connected to Edelény, the human potential was far lower than the settlements connected to Encsi and Szikszó. By 2001 a significant decrease was observable in most of the settlements, whereas by 2011 the measurable human potential value was getting lower and lower. As far as the potential values are concerned, the most significant decreases were observable in Balajt, Ládbesenyő, Damak, Gadna from 1990 to 2001. The values were derogated in Gibárt, Abaújszolnok, Abaújlak and Gadna by 2011 from 2001. In the values we could observe a small range of derogation in Edelény, Encs and Hangács. In light of the human potential, South- Cserehát shows a nearly uniform picture, without any breaking derogation. In most of the three micro regions there are stronger human development settlements that drop off the regional average $(0,151)$, but it is not very significant.

I have represented the settlements of South-Cserehát with the actual human potential values in the examined three census years (see Appendix 1.). 
The grouping was represented according to the quintile in the settlements of SouthCserehát (Fig. 10). The groups of human potential values in a settlement level show interesting configuration changes.

Figure 10 The human potential quintile of South-Cserehát (THP) (1990., 2001., 2011. year)

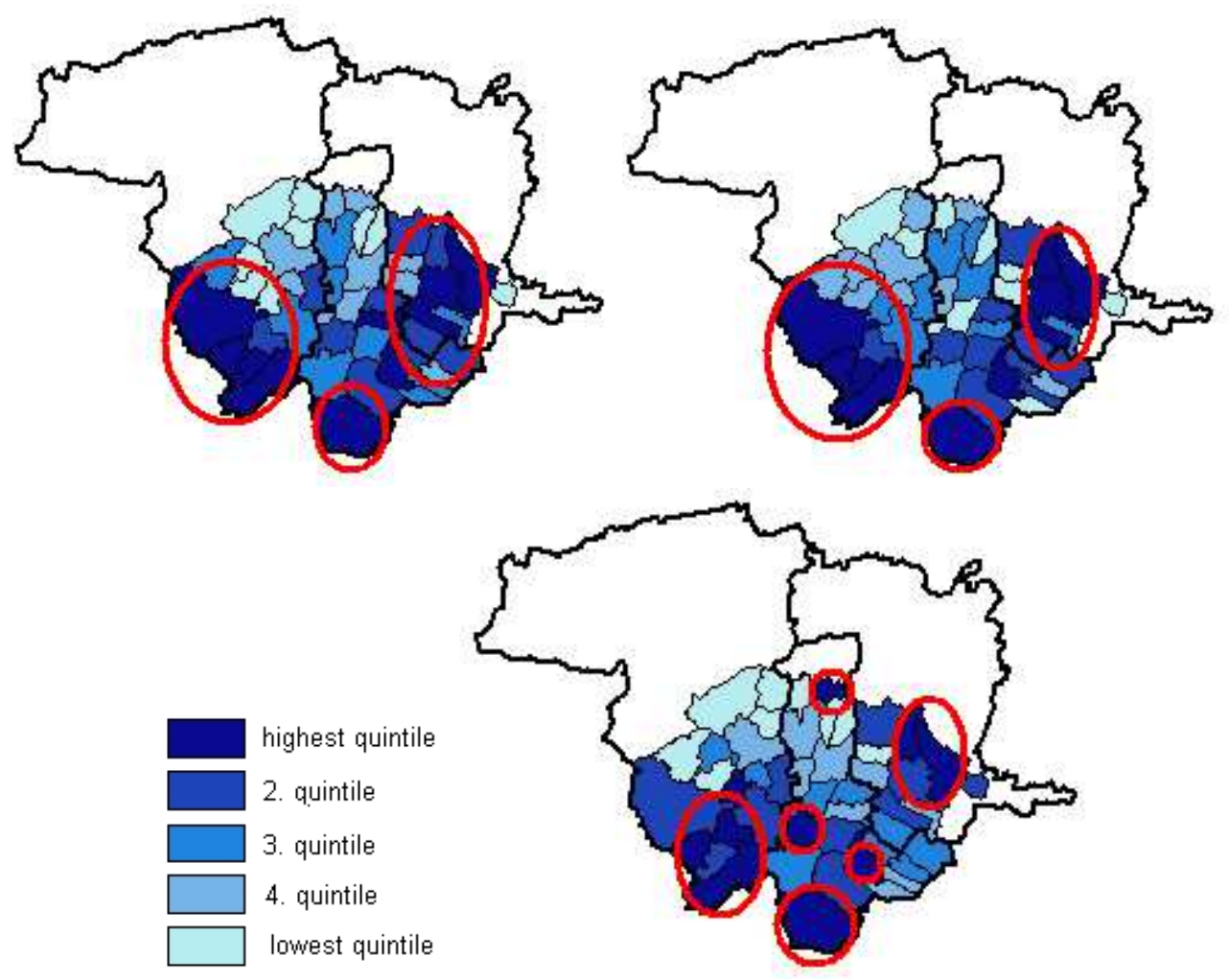

Source: Own compilation based on own calculation

In 1990 three settlement circles with fairly strong regional potential can be observed in the map: first is Edelény, Borsodszirák, Ziliz and Boldva circle, the next one is Szikszó settlement and the third circle Fancsal, Encs and Hernádszentandrás. This situation changed a little by 2001, but the former triple configuration was retained. But by 2011 an absolute multipolar configuration has formed in regard to human development. Borsodszirák, Boldva, Damak and Hegymeg made a group, Szikszó, Homrogd, Halmaj and Abaújlak transformed to four single power-centres and Fancsal, Encs made another big grouping. In the changes of 2011, the income increasing values had a hard affective power. The strengthening of Abaújlak is surprising but can be explained by the closeness of Szanticska and its income increasing power from tourism. Recruitment of Homrogd and Halmaj isn't surprising because their size makes them significant settlements of the region, except for the cities. Stunning and depressing, the city of Edelény has dropped out the circle of the strongs by 2011. That can be explained by the increasing rate of the aging index. 


\section{SUMMARY}

The following can be said to the question formulated in the introduction: the human potential values in the two-third settlements of South-Cserehát has decreased by 40 per cent in under 20 years, whereas a smaller decrease was observed in the other settlements. (Stagnation of the values wasn't significantly revealing.) Within the South-Cserehát, the range of decreasing was more dynamic from 1990 to 2001 (total: 2,072 percentage point), than from 2001 by 2011, when only a slight improvement was observable (total. 0,917 percentage point). The development of human potential in South-Cserehát region doesn't show a significant miss compared to the national average. At the same time, the numerical results of the estimation must be handled with hesitation. They can be made perfect with a minimum and maximum optimized variant used in the sub-index calculations. For myself, the given results are eligible for the thesis of configuration and they can adjust to the territorial changes proved by other researchers.

\section{REFERENCES}

Bhatnager, R.K. (2002): Constructing the Human Development Index: Effect of the adaptive multi-step formulation of utility function - a research note, South Asia Economic Journal, vol 3. issue 2. 253-263.

Csite, A. - Németh, N. (2007): Az életminőség területi differenciái Magyarországon: A kistérségi szintü HDI becslés lehetőségei, Budapesti Munkagazdaságtani Füzetek, MTA-KTI no. $3.67 \mathrm{p}$.

Farkas, M.B. (2012): A korrigált humán fejlettségi mutató kistérségek közötti differenciáltsága Magyarországon, Területi Statisztika, vol. 52 no. 3. pp. 230-249.

G.Fekete É. (2015): A társadalmi innovációk a felzárkóztatás szolgálatában, Dél-Cserehát: nyitás a jövőre, Miskolc, $213 \mathrm{p}$.

HDR (2014): Human Development Report- Sustaining Human Progress, UNDP

Husz, I. (2001): Az emberi fejlődés indexe, Szociológiai Szemle vol. 10 no. 2. pp. 72-83.

Kovacevic, M. (2010): Review of HDI Critiques and Potential Improvements, Human Development Research Paper, 33. UNDP

Kristóf, T. (2003): Magyarország gazdasági fejlettségének lehetséges forgatókönyvei, Statisztikai Szemle, vol. 81. no. 12. pp. 1090-1104.

Lipták, K. (2009): Development or decline? Determination of human development at subregional level with the estimation of HDI, EU Working Papers 12(4): 87-103.

Lipták, K. (2013): A globalizáció hatása a regionális foglalkoztatás fejlödésére kiegyenlítődés vagy leszakadás?, Ph.D. értekezés, Miskolc

Obádovics, Cs. - Kulcsár, L. (2003): A vidéki népesség humánindexének alakulása Magyarországon, Területi Statisztika, vol. 43. no. 4. pp. 303-322.

Population Census (2011): http://www.ksh.hu/nepszamlalas/ 
Rechnitzer, J - Smahó, M. (2006): Regional Characteristics of Human Resources in Hungary During the Transition, Discussion Paper no. 50. Pécs, 100 p.

The Cserehát Programme UNDP

http://www.undp.org/content/undp/en/home/search.html?q=csereh\%C3\%A1t

Appendix 1 The human potential values of the settlements in South-Cserehát

\begin{tabular}{|c|c|c|c|c|c|c|c|}
\hline Settlement & 1990 & 2001 & 2011 & Settlement & 1990 & 2001 & 2011 \\
\hline Abaújlak & 0,187 & 0,124 & 0,241 & Hernádkércs & 0,184 & 0,142 & 0,188 \\
\hline Abaújszolnok & 0,142 & 0,086 & 0,111 & Hernádszentandrás & 0,217 & 0,168 & 0,155 \\
\hline Abod & 0,000 & 0,105 & 0,143 & Homrogd & 0,239 & 0,187 & 0,218 \\
\hline Alsóvadász & 0,226 & 0,166 & 0,185 & Ináncs & 0,259 & 0,190 & 0,210 \\
\hline Aszaló & 0,244 & 0,179 & 0,197 & Irota & 0,153 & 0,141 & 0,000 \\
\hline Baktakék & 0,235 & 0,182 & 0,197 & Kázsmárk & 0,218 & 0,175 & 0,190 \\
\hline Balajt & 0,000 & 0,130 & 0,130 & Kiskinizs & 0,235 & 0,182 & 0,176 \\
\hline Beret & 0,205 & 0,104 & 0,148 & Kupa & 0,218 & 0,126 & 0,164 \\
\hline Boldva & 0,271 & 0,202 & 0,214 & Ládbesenyő & 0,000 & 0,139 & 0,189 \\
\hline Borsodszirák & 0,266 & 0,200 & 0,220 & Lak & 0,197 & 0,132 & 0,164 \\
\hline Csobád & 0,227 & 0,176 & 0,186 & Léh & 0,247 & 0,166 & 0,169 \\
\hline Damak & 0,000 & 0,151 & 0,227 & Monaj & 0,168 & 0,100 & 0,184 \\
\hline Detek & 0,164 & 0,123 & 0,157 & Nagykinizs & 0,208 & 0,172 & 0,169 \\
\hline Edelény & 0,291 & 0,205 & 0,212 & Nyésta & 0,151 & 0,143 & 0,000 \\
\hline Encs & 0,335 & 0,239 & 0,219 & Nyomár & 0,235 & 0,184 & 0,226 \\
\hline Fancsal & 0,242 & 0,193 & 0,218 & Rásonysápberencs & 0,231 & 0,177 & 0,184 \\
\hline Felsődobsza & 0,229 & 0,184 & 0,182 & Selyeb & 0,204 & 0,151 & 0,155 \\
\hline Felsővadász & 0,216 & 0,149 & 0,153 & Szakácsi & 0,145 & 0,090 & 0,088 \\
\hline Forró & 0,280 & 0,199 & 0,206 & Szendrőlád & 0,220 & 0,139 & 0,136 \\
\hline Gadna & 0,169 & 0,099 & 0,093 & Szentistvánbaksa & 0,211 & 0,100 & 0,164 \\
\hline Gibárt & 0,000 & 0,000 & 0,203 & Szikszó & 0,289 & 0,219 & 0,215 \\
\hline Halmaj & 0,286 & 0,208 & 0,219 & Tomor & 0,232 & 0,150 & 0,192 \\
\hline Hangács & 0,225 & 0,168 & 0,191 & Ziliz & 0,255 & 0,194 & 0,211 \\
\hline Hegymeg & 0,186 & 0,128 & 0,187 & & & & \\
\hline
\end{tabular}

Source: Own compilation 